\title{
Effect of starch-based biomaterials on the in vitro proliferation and viability of osteoblast-like cells
}

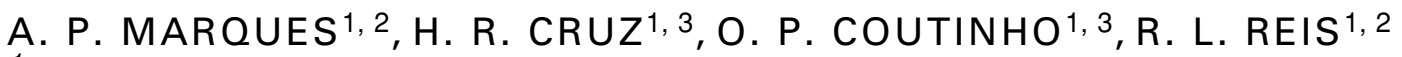 \\ 13B's Research Group-Biomaterials, Biodegradables, Biomimetics, University of Minho, \\ Campus de Gualtar, 4710-057 Braga, Portugal \\ ${ }^{2}$ Department of Polymer Engineering, University of Minho, Campus de Azurém, 4810-058 \\ Guimarães, Portugal \\ ${ }^{3}$ Department of Biology, University of Minho, Campus de Gualtar, 4710-057 Braga, Portugal
}

The cytotoxicity of starch-based polymers was investigated using different methodologies. Poly-L-lactic acid (PLLA) was used as a control for comparison purposes. Extracts of four different starch-based blends (corn starch and ethylene vinyl alcohol (SEVA-C), corn starch and cellulose acetate (SCA), corn starch and polycaprolactone (SPCL) and starch and poly-lactic acid (SPLA70) were prepared in culture medium and their toxicity was analysed. Osteoblast-like cells (SaOs-2) were incubated with the extracts and cell viability was assessed using the MTT test and a lactate dehydrogenase (LDH) assay. In addition DNA and total protein were quantified in order to evaluate cell proliferation. Cells were also cultured in direct contact with the polymers for 3 and 7 days and observed in light and scanning electron microscopy (SEM). LDH and DNA quantification revealed to be the most sensitive tests to assess respectively cell viability and cell proliferation after incubation with starch-based materials and PLLA. SCA was the starch blend with higher cytotoxicity index although similar to PLLA polymer. Cell adhesion tests confirmed the worst performance of the blend of starch with cellulose acetate but also showed that SPCL does not perform as well as it could be expected. All the other materials were shown to present a comparable behaviour in terms of cell adhesion showing slight differences in morphology that seem to disappear for longer culture times.

The results of this study suggest that not only the extract of the materials but also their three-dimensional form has to be biologically tested in order to analyse material-associated parameters that are not possible to consider within the degradation extract. In this study, the majority of the starch-based biomaterials presented very promising results in terms of cytotoxicity, comparable to the currently used biodegradable PLLA which might lead the biocompatibility evaluation of those novel biomaterials to other studies.

(c) 2005 Springer Science + Business Media, Inc.

\section{Introduction}

Biocompatibility assessment comprehends several hierarchical stages each one of them aiming to evaluate the effect of different characteristics/properties of newly developed biomaterials on the biological system. The emergence of novel biomaterials, in particular biodegradables, demands an adaptation of the existing test systems in accordance to their new properties. Several variables have emerged when evaluating the biocompatibility of those materials. The possible effects of the metabolites resulting from the degradation, the local and remote interactions of cells with those products and the rate and mechanism of degradation have been the focus of some studies [1-4].

The toxic effect of the proposed biomaterials on cells is considered one of the most important issues to be evaluated. Toxicity involves the disturbance of cellular homeostasis [5] therefore affecting cellular functions that can be very subtle or lead to a multiplicity of biochemical changes. Within cellular phenomena high importance is given to cell death, cell proliferation, cell morphology and cell adhesion, which directly correlate with toxicity in vitro [5-7]. Loss of viability constitutes the critical consequence generated by a toxic biomaterial. A reduced biosynthetic activity [8] as well as the release of cytoplasmic metabolites [9] or uptake of non-viable stains [10], resulting from cell membrane rupture, might be indicators of cell death. In hostile environments, anchorage-dependent cells become round, detach from the substratum and die [11]. The evaluation of cell morphology is therefore a rather simple and reliable tool to predict and identify loss of cellular viability. Another sign of toxicity is a reduced proliferation rate. Several methods [8, 12] have been used to quantify cell proliferation mainly based in the quantification of total protein or DNA and in the measurement of DNA 
synthesis following the incorporation of radiolabelled molecules.

Considering cell adhesion, it is important to emphasize that a reduced cell adhesion might not be indicative of cell death and consequently cannot be interpreted as a toxic effect [5]. In fact, if using anchorage-dependent cells, representative of the environment that the implant will face, cell adhesion is required and its absence would be considered an indication of poor biocompatibility. This should be allied to a morphological evaluation of the cells which would allow to confirm the eventual reduced cell adhesion as a signal of toxicity.

Several biodegradable polymers have been proposed for a wide range of biomedical applications [2, 3, 13-18]. Some of them were considered to induce an appropriate biological response in vitro $[15,16,18]$ and in vivo $[2,16]$ while others provoked a negative biological effect $[3,13,14,17,19]$. However those materials do not exhibit comparable physical, chemical or biological properties to natural tissues therefore, the search for novel materials, which resemble living systems constitutes one of the major challenges for biomaterials scientists. Natural origin materials, due to their structural similarities to components in host tissues, their possibility of being enzymatically degraded in biological systems allowing for a better control of the degradation rate along with other properties, have been presented as potential solutions for the lack of biocompatibility of currently used devices [20-24]. Starch-based materials have revealed promising properties envisaging their use in a wide range of biomedical applications [25-28]. Therefore the aim of the present work was to evaluate the cytotoxicity of several starch-based materials (commercial environmental applications grade) and the most currently used biodegradable material, poly-L-Lactic acid (PLLA, medical grade) in order to compare the performance of the different polymers. Cell viability and cell proliferation were the two parameters chosen to assess the cytotoxicity of the extracts of the materials and each one of the variables was quantified using two different techniques. Cells were also cultured in direct contact with the materials in study in order to compare the cell behaviour with the cytotoxicity results trying to identify potential additional negative effects of the surface of the materials.

\section{Materials and methods}

\subsection{Materials}

The materials studied were: (i) a 50/50 (wt\%) blend of corn starch and ethylene vinyl alcohol (SEVA-C), (ii) a $50 / 50$ (wt $\%$ ) blend of corn starch and cellulose acetate (SCA), (iii) a 30/70 (wt\%) blend of corn starch and polycaprolactone (SPCL) and (iv) a 30/70 (wt\%) blend of corn starch and poly-lactic acid (SPLA70).

Poly-L-Lactide (Purac biochem bv, The Netherlands), being the gold standard for biodegradables in biomedical applications, was used as a biodegradable control material and latex rubber as a positive control.

All the materials, except latex, were processed into circular samples $(\varnothing 1 \mathrm{~cm})$ by injection moulding and sterilised by ethylene oxide (EtO) under the conditions previously described [25].

\subsection{Cell culture}

A human osteosarcoma cell line SaOs-2, an immortalized cell line with an osteoblastic phenotype, was obtained from European Collection of Cell Cultures (ECACC, UK). The cells were cultured in Medium 199 without phenol red (DMGibco BRL, Life Technologies, USA) supplemented with $10 \%$ of heat-inactivated fetal bovine serum (FBS; Biochrom AG, Germany), $100000 \mathrm{U} / \mathrm{ml}$ penicillin-G, $100 \mu \mathrm{g} / \mathrm{ml}$ streptomycin and $25 \mu \mathrm{g} / \mathrm{ml}$ amphotericin B (Sigma Chemical Co., USA) and $20 \mathrm{mM}$ Hepes (Sigma Chemical Co., USA) in a humidified atmosphere with $5 \% \mathrm{CO}_{2}$ and at $37^{\circ} \mathrm{C}$.

In preparation for the MTT, Total Protein and LDH quantification tests cells were resuspended in culture medium at a density of $6.6 \times 10^{4}$ cells $/ \mathrm{ml}$ and seeded (200 $\mu \mathrm{l} /$ well) in 96-well plates. For the DNA quantification, cells were resuspended in culture medium at a density of $2.4 \times 10^{5}$ cells $/ \mathrm{ml}$ and seeded $(1 \mathrm{ml} / \mathrm{well})$ in 24-well plates.

All the plates were then incubated for $48 \mathrm{~h}$ at $37^{\circ} \mathrm{C}$ in a humidified atmosphere of $5 \% \mathrm{CO}_{2}$ in order to establish a 90-100\% confluence monolayer.

\subsection{Extract preparation}

Materials $\left(3 \mathrm{~cm}^{2} / \mathrm{ml}\right)$ were incubated in $10 \mathrm{ml}$ of culture medium for $24 \mathrm{~h}$ at $37^{\circ} \mathrm{C}$ with constant shaking (60 $\mathrm{rpm}$ ) in order to simulate better the short-term effect of the degradation products under conditions similar to those of human body, a dynamic environment. The extract was then filtered $(0.45 \mu \mathrm{m}$ pore size $)$ to eliminate the possible presence of solid particles of the material and serial dilutions $(25,50$ and $75 \%)$ in culture medium were prepared.

\subsection{MTT assay}

Culture medium was replaced by the extracts of the materials ( $150 \mu \mathrm{l} /$ well) after cells reached the confluent monolayer and plates were incubated for $72 \mathrm{~h}$.

After incubation medium was removed, each well was treated with $50 \mu \mathrm{l} /$ well of MTT $(1 \mathrm{mg} / \mathrm{ml}$ in medium 199 without phenol red, Sigma, St. Louis, USA) and plates incubated for further $4 \mathrm{~h}$ at $37^{\circ} \mathrm{C}$ in a humidified atmosphere of $5 \%$ of $\mathrm{CO}_{2}$. At this stage the MTT was removed and $100 \mu \mathrm{l} /$ well of isopropanol (Merck, Germany) was added in order to dissolve the formazan crystals. The plates were placed in the incubator for $15 \mathrm{~min}$ and then in a cold room for $15 \mathrm{~min}$ before the absorbance measurements. The optical density (OD) was read on a multiwell microplate reader (Molecular Devices SPECTRAMax Plus 340PC, USA) at $570 \mathrm{~nm}$.

\subsection{LDH quantification}

Plates were treated with the extracts of the different materials as described for MTT test, but reserving replicates to determine total and extracellular LDH. After the $72 \mathrm{~h}$ of incubation $50 \mu \mathrm{l}$ of $10 \mathrm{mMHEPES}$ solution were added to each well. The solution of the wells reserved to determine extracellular LDH was transferred to new 96-well plates. The lysis of the cells adhered to the initial 96-well plates was promoted by 
3 consecutive cycles of $-80^{\circ} \mathrm{C}$ for $10 \mathrm{~min}$ and $37^{\circ} \mathrm{C}$ for $5 \mathrm{~min}$ and the suspension removed to another 96-well plates to quantify total $\mathrm{LDH}$. Both for extracellular and total LDH quantification, $10 \mu \mathrm{l}$ of each sample were incubated with $50 \mu \mathrm{l}$ of pyruvate $(9.76 \mathrm{mM}$ pyruvate in $81.3 \mathrm{mM}$ Tris/203.3 mM NaCl, $\mathrm{pH} 7.2$ ) and the reaction was started with $125 \mu$ l of NADH (0.244 mM NADH in $81.3 \mathrm{mM}$ Tris/203.3 mM NaCl, $\mathrm{pH}$ 7.2). Blank was read using $50 \mu \mathrm{l}$ of $81.3 \mathrm{mM}$ Tris $/ 203.3 \mathrm{mM} \mathrm{NaCl}$, $\mathrm{pH} 7.2$ instead of pyruvate. The LDH activity was followed through the rate of oxidation of NADH to NAD ${ }^{+}$ for $150 \mathrm{~s}$ at $340 \mathrm{~nm}$ (Molecular Devices SPECTRAMax Plus 340PC, USA) and the $V_{\max }\left(\mathrm{OD}_{340 \mathrm{~nm}} \times 10^{-3} / \mathrm{min}\right)$ determined.

\subsection{DNA quantification}

After reaching confluence, the culture medium was replaced by serial dilutions of the extract (600 $\mu \mathrm{l} /$ well) of each material. Culture medium without any extract was used as control. After $72 \mathrm{~h}$, the extracts were removed, $200 \mu \mathrm{l}$ of $0.25 \%(\mathrm{v} / \mathrm{v})$ trypsin/EDTA solution (Sigma Chemical Co., USA) added to each well for $5 \mathrm{~min}$ and replaced by $1 \mathrm{ml}$ of PBS $0.01 \mathrm{M}$. The solution was homogenised with a micropipette in order to remove all the cells still adhered and transferred to new test tubes. Tubes were centrifuged for $10 \mathrm{~min}$ at $2500 \mathrm{rpm}$ and $4{ }^{\circ} \mathrm{C}$, the supernatants rejected and the pellets resuspended in $5 \mathrm{ml}$ of Proteinase K solution previously prepared with $2.5 \mathrm{ml} \mathrm{NaCl} 4 \mathrm{M}, 20 \mathrm{ml}$ EDTA $500 \mathrm{mM}, 5 \mathrm{ml}$ Tris $2 \mathrm{M}, \mathrm{pH}=8.0,25 \mathrm{ml} \mathrm{SDS} 10 \%$ (w/v) and $525 \mu \mathrm{l}$ of Proteinase K $(10 \mathrm{mg} / \mathrm{ml})$. Tubes were incubated overnight at $37^{\circ} \mathrm{C}$. Following incubation $1.5 \mathrm{ml}$ of water plus $1.5 \mathrm{ml}$ of $\mathrm{NaCl}$ were added to each tube. These were mixed for $30 \mathrm{~s}$ and centrifuged for $3 \mathrm{~min}$ at $4000 \mathrm{rpm}$ and $4{ }^{\circ} \mathrm{C}$. Supernatants were transferred to new tubes, $6 \mathrm{ml}$ of $70 \%$ ethanol (v/v) were added and the mixtures homogenised until DNA precipitated. Tubes were left to stabilise for $1 \mathrm{~h}$, the supernatants discarded and the precipitate transferred to eppendorfs to which $200 \mu \mathrm{l}$ of $70 \%$ ethanol (v/v) and $150 \mu \mathrm{l}$ of Tris- $\mathrm{HCl} 10 \mathrm{mM} / \mathrm{EDTA} 1 \mathrm{mM}$ were added.

The DNA concentration was determined reading the optical density at $260 \mathrm{~nm}$, using the same equipment referred to before.

\subsection{Total protein quantification}

As for the DNA quantification, after reaching confluence the culture medium was replaced by serial dilutions of the extract ( $150 \mu \mathrm{l} /$ well) of each material. Culture medium without any extract was used as control. In the end of the incubation time $(72 \mathrm{~h})$ the extracts were removed, cells were washed with $0.1 \mathrm{M}$ PBS and let in $100 \mu \mathrm{l}$ of PBS $0.1 \mathrm{M}$. From this point on, the BCA Protein Assay kit (Pierce Chemical Co., USA) was used. This system utilises bicinchoninic acid (BCA) as the detection reagent for $\mathrm{Cu}^{+1}$, which is formed when $\mathrm{Cu}^{+2}$ is reduced by protein in an alkaline environment. The purple coloured reaction product is formed by the chelation of two molecules of BCA with one cuprous ion $\left(\mathrm{Cu}^{+1}\right)$. This water-soluble complex exhibits a strong absorbance at $562 \mathrm{~nm}$ that is linear with increasing protein concentration.

\subsection{Direct contact assay}

The materials were placed in contact with cells during different time periods in order to identify morphological changes resulting from this contact and to see how cells were adhered and spread on the material.

In this assay cells were trypsinised $(0.25 \%(\mathrm{v} / \mathrm{v})$ trypsin/EDTA solution, Sigma Chemical Co., USA) from a culture flask and $1.5 \mathrm{ml}$ of cell suspension, in fresh culture medium $\left(3.3 \times 10^{-4}\right.$ cells $\left./ \mathrm{ml}\right)$ were seeded onto the materials. Three samples, per material, per time of growth, were studied and tissue culture polystyrene wells were used as control. The 24-well plates were incubated for 3 and 7 days. Culture medium was changed on the third day and after each pre-determined time of culture the cells were washed with a $0.1 \mathrm{M}$ phosphate buffered saline solution (PBS, Sigma Chemical Co., USA), fixed with $2.5 \%$ gluteraldehyde (BDH, UK) solution in PBS for $30 \mathrm{~min}$ at $4{ }^{\circ} \mathrm{C}$, washed and kept in $\mathrm{PBS}$ at $4{ }^{\circ} \mathrm{C}$ until being stained or prepared for scanning electron microscopy (SEM) observation.

The surface of the materials was therefore stained with a $0.4 \%$ methylene blue solution in water for $1 \mathrm{~min}$ and examined in a stereomicroscope Zeiss KL 1500 (Zeiss, Germany). For SEM, samples were dehydrated in graded ethanol solutions (70, 90, and 100\%) twice, 15 min each and let to dry overnight. Samples were gold sputter coated in a Sputter Jeol JFC 1100 and observed on a Leica Cambridge S360 SEM equipment (Leica Cambridge, UK).

\subsection{Statistical analysis}

All materials extracts were tested in 12 (Total protein and MTT tests) and 6 (Total DNA and LDH tests) replicates for each extract concentration for a minimum of three separate experiments with comparable results.

All data was averaged and standard deviation is reported as a measure of sample deviation. The data for the neat extracts was statistically compared by a one way ANOVA analysis using a Tukey test [29]. If probability values were less than $0.05(p<0.05)$, differences observed for the two materials were considered statistically significant.

\section{Results}

MTT and LDH quantification were used to measure cell viability while cell proliferation was assessed by DNA and total protein quantification. These methodologies were applied after culturing an osteoblast-like cell line with the extracts of biodegradable polymers. Before each test, cells were seeded in different densities and allowed to adhere overnight to confirm that each one of the parameters was linearly correlated with the cell number and to define the cell seeding concentration.

\subsection{Cell viability}

The MTT assay revealed that the extracts of all the materials in study affected the viability of osteoblast-like 


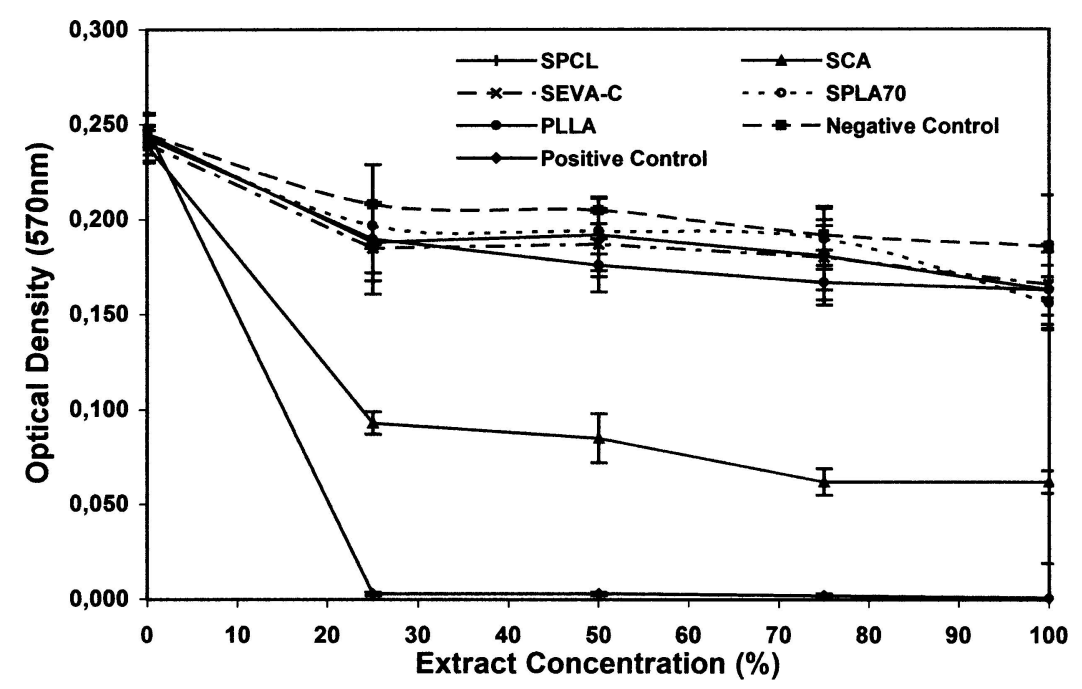

Figure 1 Effect of the concentrations of the extract of several starch-based polymers on cell viability when compared with controls and reference materials. The results obtained in the presence of neat extract of SCA were found to be significantly different from the results obtained in the presence of all the other materials. In addition, when comparing SEVA-C and SPLA70, their effect on cell viability was found to be significantly different.

cells. This was expected due to the biodegradable nature of the polymers. It was possible to observe (Fig. 1) that the extract of the polymer of starch with cellulose acetate induced the highest percentage of cell death (about $75 \%$ ). While in the presence of the extracts of all the other materials the number of viable cells was comparable to the number of viable cells in the negative control (TCPS), in the case of SCA its behaviour was closer to the positive control (latex). In fact, the percentage of cell death in the presence of the extracts of starch-based materials (except SCA) and PLLA was around $30 \%$, which can be considered a good result for this type of polymeric biomaterials.

The statistical analysis of the results obtained for the neat extract confirmed that the effect of SCA extracts was significantly different from all the other materials. In addition, only the extract of SEVA-C was found to be significantly different from the extract of SPLA70 which suggests that the extract of SEVA-C was the less toxic (31\% of cell death) and that SPLA70 was the material with second highest index of cytotoxicity (36\% of cell death).

It is known that the intracellular LDH is proportional to the number of cells [9]. This parameter was determined subtracting the extracellular $\mathrm{LDH}$ to the total $\mathrm{LDH}$, in order to obtain the number of viable cells and compare the results with those obtained in the MTT test. In fact, although with some differences, the same tendency was observed with the LDH quantification experiment. The incubation of osteoblast-like cells with the extracts of the polymers induced a decrease in the number of viable cells (Fig. 2). Once again, the extract of SCA induced highest percentage of cell death (about 46\%). However, this was a less pronounced reduction, comparatively to the result obtained for MTT quantification.

The statistical analysis of the results however, evidenced significant differences between the materials. While the SCA effect was found to be significantly different from all the other polymers with the MTT

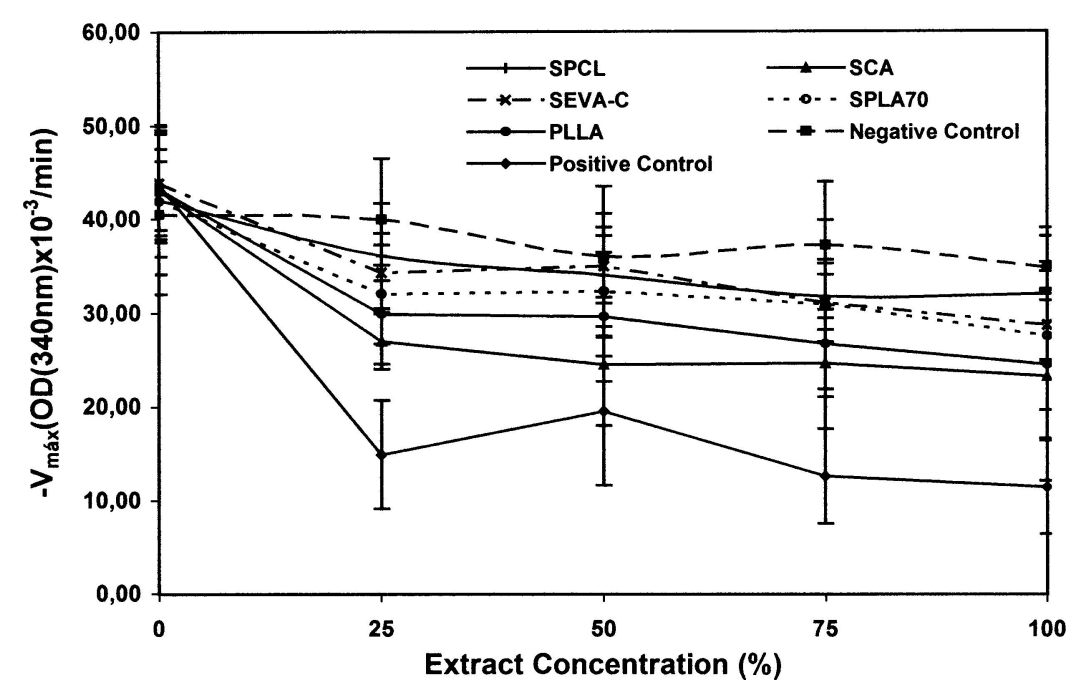

Figure 2 Effect of the concentrations of the extract of several starch-based polymers on the intracellular LDH activity when compared with controls and reference materials. The results obtained in the presence of neat extract of SEVA-C were found to be significantly different from the results obtained in the presence of SCA and PLLA. Furthermore, SPCL was found to induce a significant different behaviour when comparing to SCA, PLLA and SPLA70. SCA and SPLA70 were also found to be different. 
test, the LDH quantification showed that SCA and PLLA induced a similar outcome. Furthermore, PLLA was also found to provoke significant and more cell death (about 44\%) than SPCL (about 24\%) and SEVAC (about 34\%). Interestingly, the toxicity of SPLA70 (about 35\%) was shown to be significantly higher than the toxicity of SPCL and lower than SCA (about $46 \%$ ) but not different from SEVA-C and PLLA. It is important to remind herein that SPCL and SPLA70 have both $30 \%$ of starch and $70 \%$ of PLA or PCL.

Thus, based on the LDH quantification, PLLA could be considered to be the material with higher index of cytotoxicity after SCA, and SPCL the less harmful. The toxicity index of SCA can be explained due to the release of low molecular weight chains to the extraction medium, which are responsible for a $\mathrm{pH}$ drop therefore inducing cell death.

\subsection{Cell proliferation}

The proliferation of osteoblast-like cells evaluated after incubation with the extracts of the degradable materials in study showed that their degradation products affect that cellular parameter (Fig. 3). The quantification of DNA showed that SEVA-C and SPCL were the two polymers which had less effect on cell proliferation, respectively 26 and $28 \%$ of growth inhibition, presenting a result close to the negative control. Again, these results are quite promising for biodegradable polymers. Furthermore the statistical comparison of the results obtained with the neat extract of those two materials and each one of the other polymers showed that the reduction in cell proliferation was significantly different. The blend of starch with poly-lactic acid followed SPCL in terms of percentage of inhibition of cell proliferation (about 31\%). PLLA was the material that provoked the second highest reduction in cell proliferation (about $35 \%$ ) and SCA was again the material with the most negative properties inducing around $57 \%$ of inhibition of osteoblast-like cells proliferation. As mentioned before, the presence of low molecular weight chains in the SCA extract affected the cellular metabolism inducing, in some cases, cell death and delaying proliferation of the less affected cells.

The quantification of total protein confirmed the majority of the results obtained with the DNA methodology (Fig. 4). Again the results obtained with the

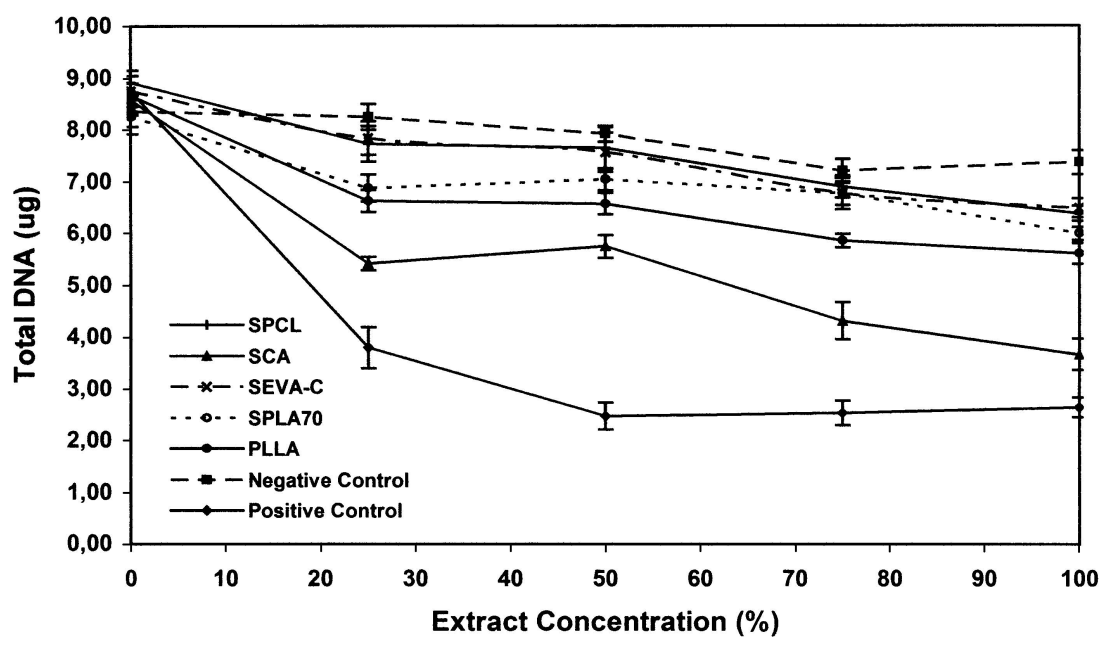

Figure 3 Effect of the concentrations of the extract of several starch-based polymers on the quantified total DNA when compared with controls and reference materials. Only in the presence of SEVA-C and SPCL neat extracts the effect in cell proliferation was found to be similar to negative control.

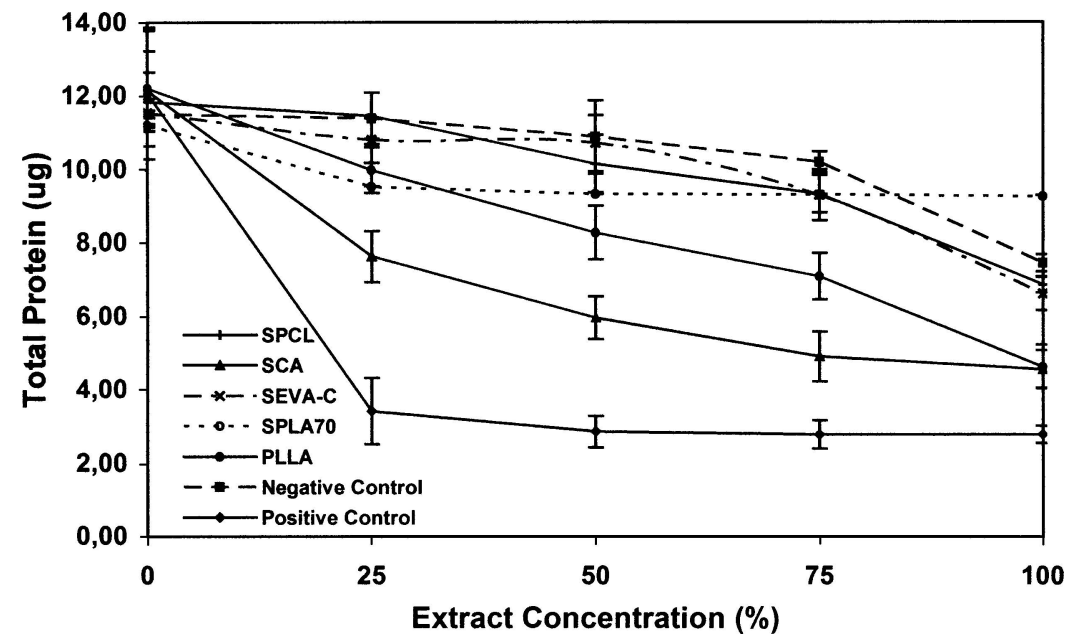

Figure 4 Effect of the concentrations of the extract of several starch-based polymers on the amount of total protein, as compared to controls and reference materials. The amount of protein and consequently the effect on cell proliferation was found not to be different between neat extracts of SEVA-C and SPCL, the less toxic, and SCA and PLLA the more harmful. 
extracts of SEVA-C and SPCL revealed to be comparable to those obtained for the negative control and significantly different from all the other materials. While those two polymers induced about $43 \%$ of inhibition in cell proliferation, SCA and PLLA which results were not statistically different, provoked an inhibition closer to the positive control and of about $63 \%$. The amount of total protein measured after incubation with the extract of SPLA70 did not show any effect with increasing concentration of extract. In fact, the cell proliferation was affected for the $25 \%$ extract concentration, with a decrease of about $17 \%$ in cell proliferation, but did not change for higher concentrations of extract. This might be an indicator that the incorporation of starch into the poly-lactic acid positively influences cell response.

Therefore, SCA together with PLLA were shown to negatively affect the proliferation of osteoblast-like cells in higher extent while SEVA-C and SPCL presented a comparable performance to TCPS.

\subsection{Cell adhesion}

The presence of a substrate to adhere constitutes an important variable in understanding the biocompatibility of newly developed biomaterials. Despite good cell behaviour in the presence of biomaterials extracts, it might be possible that, when in direct contact with the materials, the surface properties are not the most suitable for an optimal cell response.

Osteoblast-like cells were therefore cultured in direct contact with the polymers in study and cell morphology was analysed after 3 and 7 days. Considering the cell viability and proliferation analysis performed with the extracts of the materials, SEVA-C and SPCL were expected to be the best surfaces for cell adhesion. Fig. 5(A) and (B) show cells adhered to the surface of SEVA-C respectively after 3 and 7 days of culture. Cells present the typical morphology of osteoblastic cells; a polygonal shape with cytoplasm extensions. SEVA-C appears to present appropriate physico-chemical properties for SaOs-2 to adhere and proliferate since the surface of the sample after 7 days of culture was almost fully covered. However, and contrarily to what was expected, cells adherent to SPCL did not show the characteristic morphology of osteoblast-like cells (Fig. 5(C) and (D)), which may prevent an adequate long-term cell response. The proliferation rate of these cells did not seem to be comparable to cells adhered to SEVA-C since SPCL surface area occupied by cells, after 7 days of culture, was less significant (Fig. 5(D)).

Like for SPCL, the extract of SPLA70 did not significantly affect the behaviour of SaOs- 2 but its adhesion performance on the surface of that polymer was not as good as it could be expected, in particular for earlier times of culture (Fig. 5(E)). Nonetheless, some of the adherent cells presented the typical morphology of osteoblast-like cells and after 7 days of culture an almost confluent layer of cells was covering the surface of SPLA70 (Fig. 5(F)) showing that cell proliferation is not affected by the surface of this polymer.

Comparing SPLA70 with PLLA, the extract of PLLA showed a more damaging effect on cell viabil- ity and proliferation. However, the surface of the material was found to induce good adhesion behaviour (Fig. 5(G) and (H)). Cells presented a morphology representative of an ideal adjustment to the surface with strong adhesion. Cell proliferation, like for SPLA70, did not seem to be affected also resulting in an almost fully covered surface after 7 days of culture (Fig. 5(H)).

Again, the worst results for SCA extracts were confirmed by the adhesion tests (Fig. 5(I) and (J)). Cells on the surface of starch with cellulose acetate presented a round morphology and did not proliferate with longer culture times.

\section{Discussion}

The present study represents a multi-endpoint approach, which provides information about different cellular functions. The aim was to use four alternative methods to determine the cytotoxicity of the degradation products of biodegradable biomaterials at different levels. As typically toxic substances do not act at one specific level but affect several cellular functions [8], we determined how toxic leachables acted at cellular and sub-cellular levels by measuring the activity of mitochondrial and cytoplasmic enzymes and quantifying DNA and total protein content.

Some discussion [23, 30-32] arises when comparing different methodologies to determine cell cytotoxicity, but statistically significant correlation between assay techniques were also reported [33, 34]. Some authors $[32,34]$ defend that the measurement of an intracellular parameter such as DNA content may be a more sensitive tool for the estimation of the cytotoxic potential of a test material. Furthermore, MacNair et al. [31] demonstrated that LDH assay is inferior in terms of sensitivity since it represents a terminal event while the measurement of total cell protein content was presented as a more sensitive index of cytotoxicity.

In this work, however, when comparing the results obtained for MTT and LDH we could suggest that intracellular LDH is a more sensitive index of toxicity. In the LDH quantification assay higher levels than originally thought (after the MTT test) as well as statistically different toxicity levels were found for the majority of the materials. As some of these materials were considered, after the MTT test, to have a similar toxic behaviour these results are clearly indicative of the higher sensitivity of the LDH technique.

Analysing the results of DNA and total protein quantification our findings are in accordance with the literature. The DNA measurement proved to be more sensitive than the determination of total protein.

Based in the obtained results, we may also speculate that proliferating cells may be more sensitive than the resting cells to a toxic challenge therefore the cytotoxicity trend be different for some materials when comparing the methodologies used to evaluate cell viability and cell proliferation.

A great challenge in the development of novel biomaterials is to support the interpretation of the cytotoxicity results in the characteristics of the materials. In particular, degradable polymers display variable 
behaviour in biological systems, depending on various properties such as molecular weight [1], hydrophobicity [35], distribution of charge [22], residual monomer [36] and $\mathrm{pH}$ of the degradation products [3]. Therefore, these factors, combined with the degradation kinetics, are important in determining the toxicity of promising biomaterials. The $\mathrm{pH}$ and osmolarity of polymer extracts have been suggested to be related to the toxicity of polymers $[4,37]$ and dependent on the amounts of

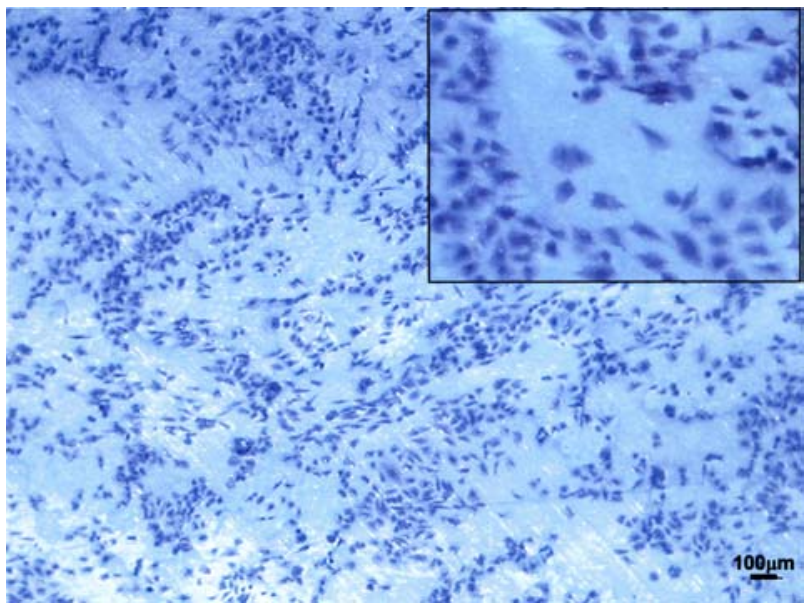

(A)

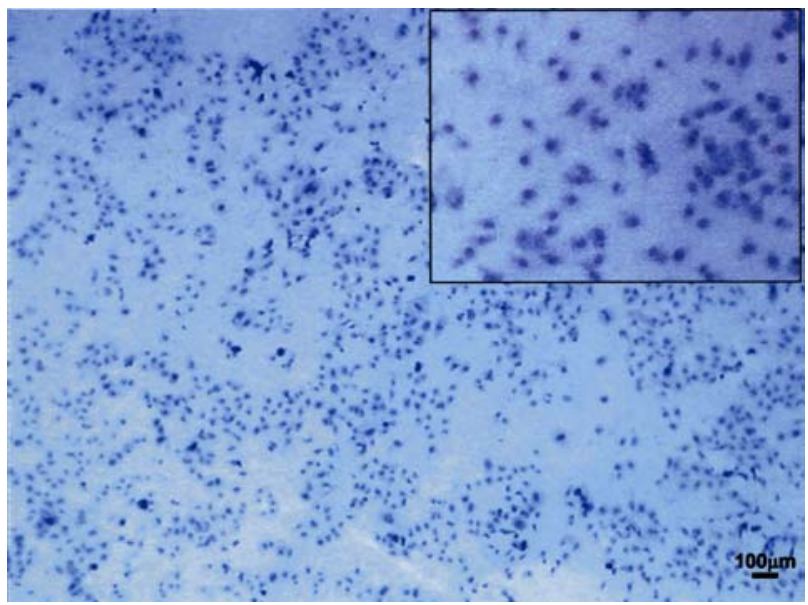

(C)

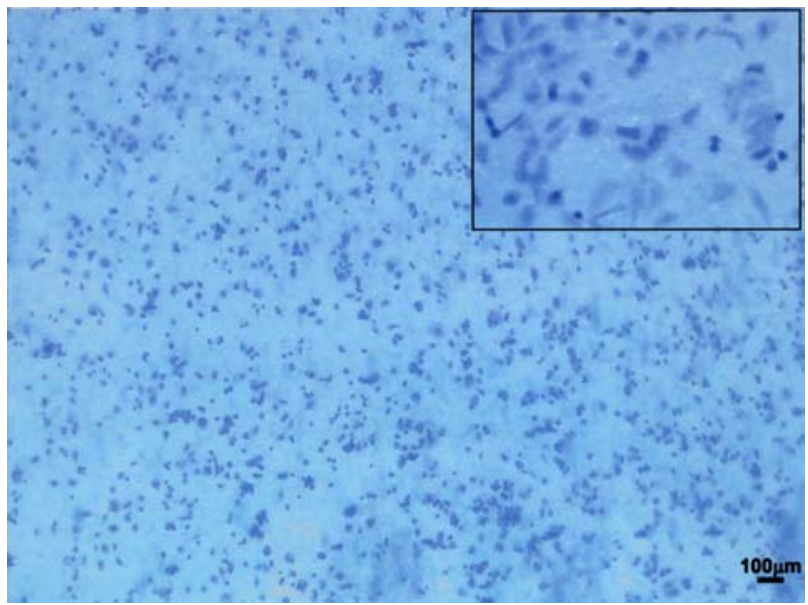

(E) solubilised monomers and oligomers [38]. In fact, $\mathrm{pH}$ influences cell behaviour and viability and acidic $\mathrm{pH}$ lower than the physical $\mathrm{pH}$ of the cells can cause a toxic response $[33,39]$. Osmolarity is a factor that can exert an influence on proliferation, morphology and cell activity [36].

From the toxicity data in this work it appears that the material with higher index of cytotoxicity is SCA. This is the material with higher capability to uptake water

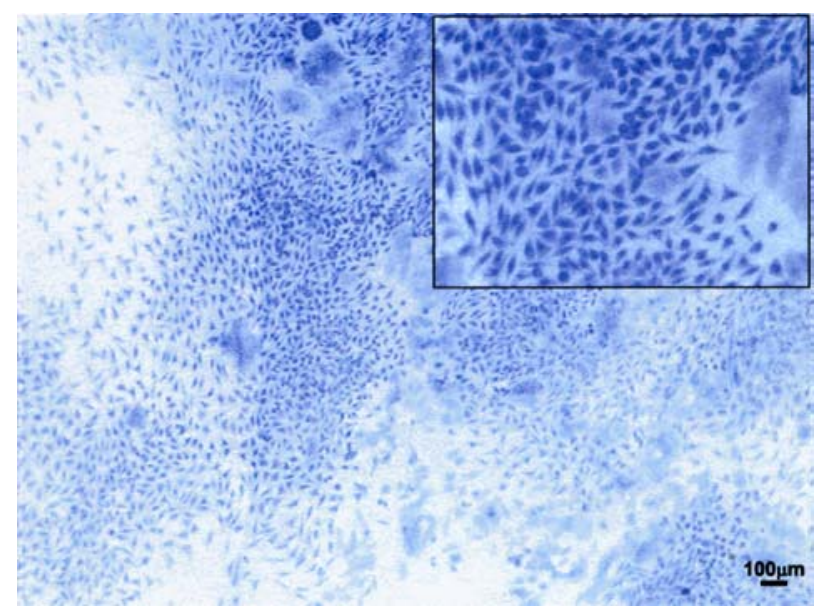

(B)

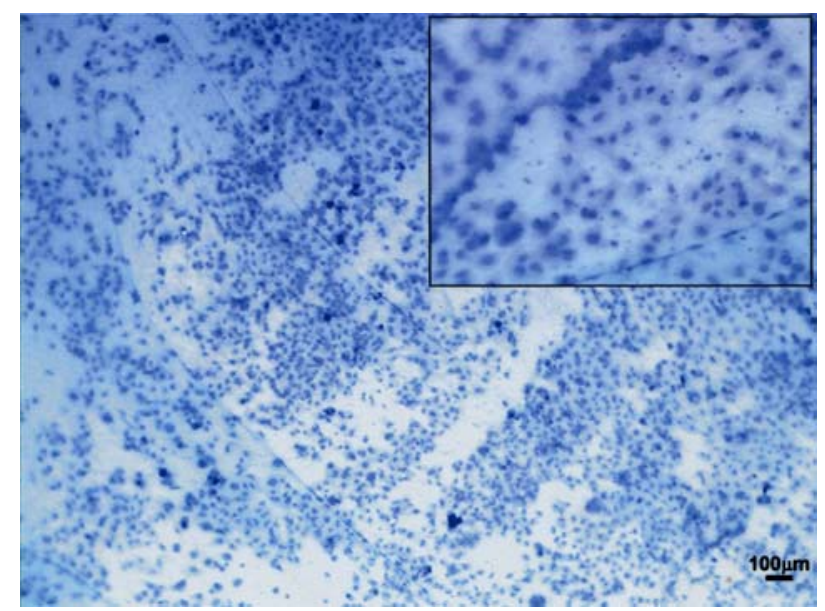

(D)

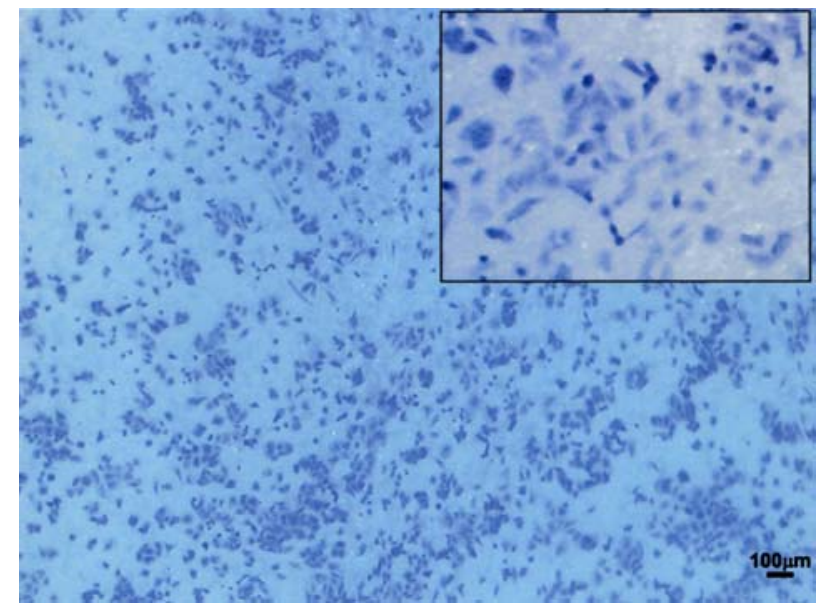

(F)

Figure 5 Optical micrographs showing SaOs-2 cultured on the surface of biodegradable polymers for 3 and 7 days and stained with methylene blue. A, B-SEVA-C; C, D-SPCL; E, F-SPLA; G, H-PLLA; I, J-SCA. A, C, E, G, I-3 days of culture; B, D, F, H, J-7 days of culture. Small squares on the upper corner represent an area of the micrograph at higher magnification. Bar represents $100 \mu \mathrm{m}$. (Continued) 


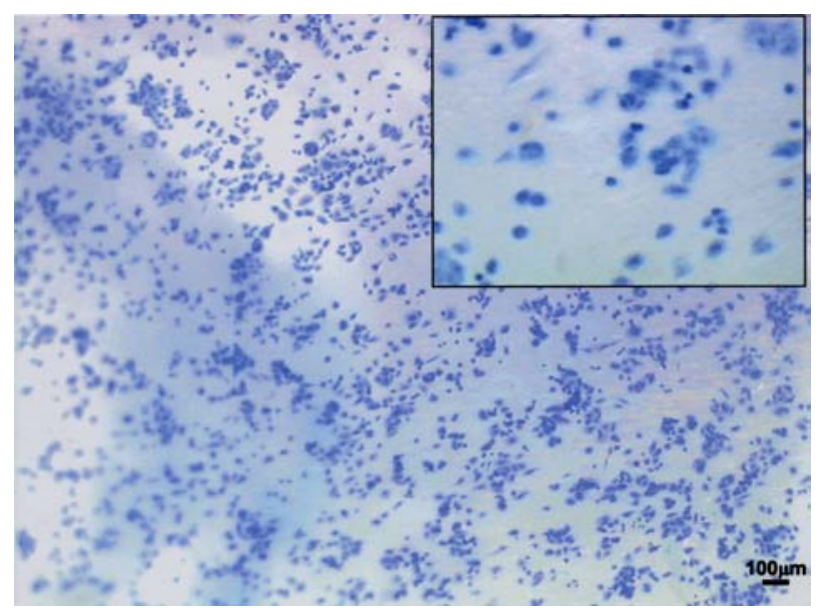

(G)

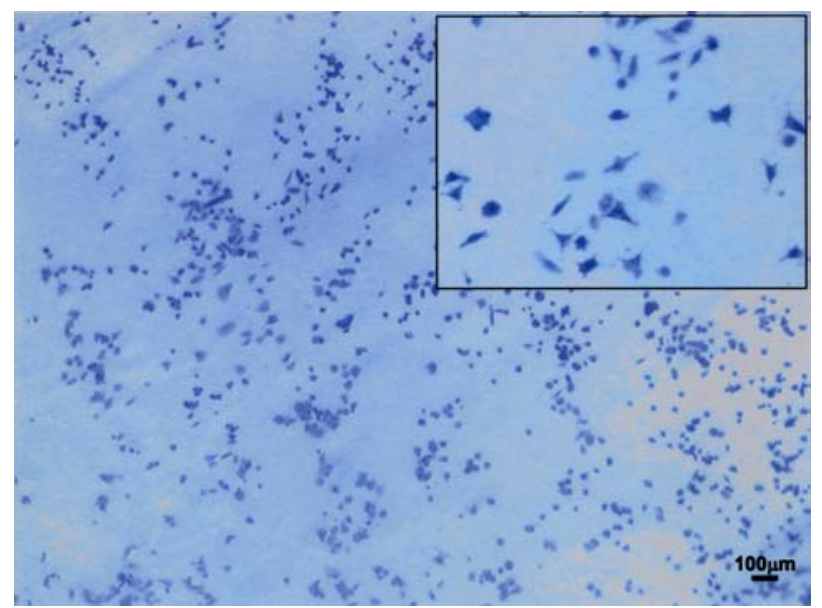

(I)

Figure 5 (Continued).

therefore with higher predisposition for degradation. In addition SCA is a non-miscible blend, which affects the kinetics of degradation releasing higher amounts of low molecular weight chains to the extraction medium at early stages of immersion. In fact, the extraction medium (culture medium with phenol red) showed a slight change of colour indicative of acidification; thus it is possible that the low molecular weight chains released to the medium are responsible for the $\mathrm{pH}$ decrease and consequently for the cytotoxicity.

The $\mathrm{pH}$ of the extraction medium does not seem to be responsible for the degree of toxicity observed for the other materials. Although not as obvious as for SCA, there are some differences between the materials, in terms of cytotoxicity, that might be attributed to the degradation products of the polymers. In fact, Ignatius et al. [12] reported studies in buffer solutions where PLLA toxicity was attributed to the degradation products themselves. In another work [4] the low $\mathrm{pH}$ of water incubated PLA specimens was attributed to their degradation and the resulting concentration of lactic acid in the exposure medium. It can be speculated that since the $\mathrm{pH}$ of the extraction medium does not change, the toxicity presented by the PLLA extracts, mainly affecting cell proliferation is due to the interaction of the cells with the products of degradation. Previous works with starch-based biomaterials [40-42], in particular with

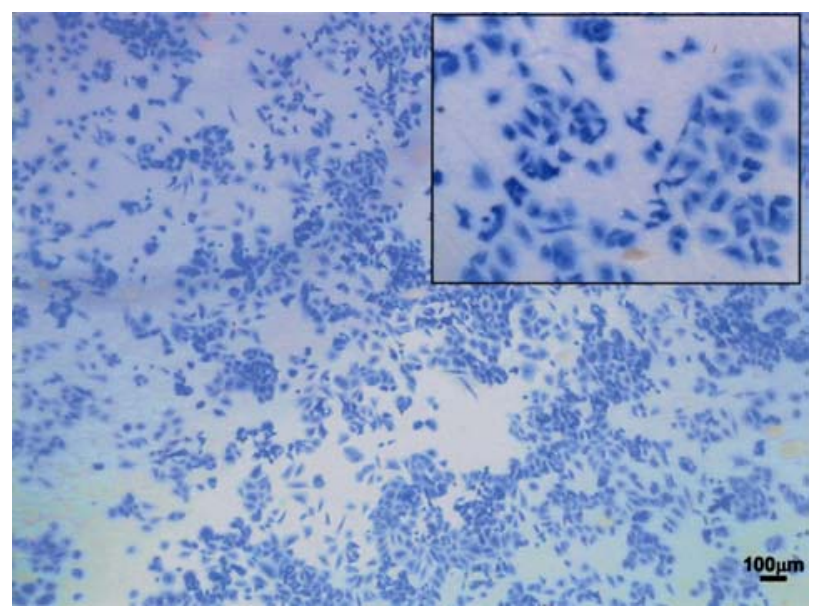

(H)

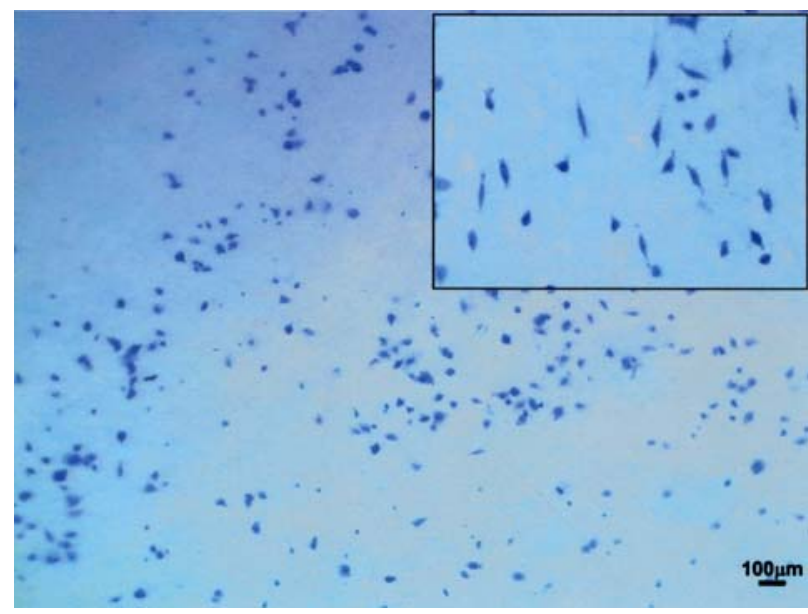

(J)

SEVA-C and SCA extracts incubated with other type of cells, have shown promising results. Thus the cytotoxicity of SCA can be attributed to the high amount of low molecular weight chains and processing additives, which can be removed by an additional processing stage [42].

Cytotoxicity tests with extracts are usually defined as indirect contact tests. Cytotoxicity tests with extracts should be complemented with direct contact tests since materials may display differences in cytotoxicity depending on cell-material contact arrangements. Cell-material contact can in a way reduce the sensitivity of an in vitro system but also influence cell viability, probably due to chemical interactions [18, 43]. The shape [44] and surface texture [43, 45] of an implant are other important factors, determining the tissue response although a conclusive mechanism is not yet established.

Cell adhesion experiments performed in this work demonstrate that besides the extracts of the materials the three-dimensional forms of the polymers have to be tested as the results of cell behaviour may drastically change. This was the case of the blend of starch with polycaprolactone (SPCL), which did not present significant toxicity but when in direct contact with the materials showed reduced cell adhesion and delayed proliferation rate. Contrarily, SCA confirmed to be the 
less suitable surface for cell adhesion as was expected by the cytotoxicity test. However, other studies [46, 47] with SPCL and SCA showed that these two materials processed under different conditions and shapes aiming for example tissue engineering purposes, support cell adhesion.

The different percentages of starch and the miscibility and the starch-based blends might also have some influence in the biological performance of those biomaterials. SEVA and SCA, both with $50 \%$ of starch could be expected to induce a similar behaviour however, SCA is a non-miscible blend, which can contribute to a completely different surface in terms of starch and synthetic component exposure and consequently cell adhesion. In addition the two starch blends with $30 \%$ of starch SPCL and SPLA70 also presented very distinct cell adhesion results. This might indicate that in this case the synthetic component rules cell adhesion and proliferation and we can speculate that increasing the percentage of starch in the blend with polycaprolactone would improve those actions.

Thus specific surface properties have pivotal role on cell adhesion behaviour. Studies with pure PCL showed that it has an hydrophilic surface and osteoblast-like cells appear to prefer more hydrophobic surfaces [35]. Contrarily, Yang et al. [18] reported less adhesion and differentiation of bone-marrow stromal cells onto hydrophobic surfaces due to less adsorption of fibronectin. The starch-based blend SPCL is more hydrophobic than the other materials which is in accordance with Yang et al. [18]. However, other authors [48] suggest that some chemical groups have more significant role in cell adhesion than the general surface properties. For example, the oxygen content of SEVA-C, lower than SPCL and SCA [49], seems to be the most suitable for the adhesion of SaOs-2 under the studied conditions.

\section{Conclusions}

The data generated by this battery of assays allow for a response on the cytotoxic potential of materials or devices with a higher grade of certainty. In addition it also provides the guarantee that if the leachables from the materials interfere with one test system the results are not misinterpreted.

It was also possible to prove that not only the extract of the materials but also their three-dimensional form has to be biologically tested in order to analyse materialassociated parameters that are not possible to consider within the degradation extract.

Therefore, both direct and indirect tests allowed to determine that SCA induced significant cytotoxicity and did not present the ideal surface properties for osteoblast-like cells adhesion and proliferation. Contrarily, SPCL extract was not deleterious for cells but did not support their proliferation. Comparatively to the gold standard biodegradable biomaterial, SEVA$\mathrm{C}$ and SPCL showed a better behaviour than PLLA in terms of cytotoxicity. The adhesion and proliferation of osteoblast-like cells on SEVA-C and SPLA70 was however, comparable to PLLA, which indicates the good potential of the majority of the starch-based biomaterials tested for bone related applications.

\section{Acknowledgments}

The authors gratefully acknowledge the Portuguese Foundation for Science and Technology (FCT) and the Portuguese Programme PRAXIS XXI for awarding a PhD Grant to A. P. Marques (SFRH/BD1276/2000).

This work was also partially supported by FCT Foundation for Science and Technology, through funds from the POCTI and/or FEDER programmes.

\section{References}

1. J. M. SCHAKENRAAD, M. J. HARDONK, J. FEIJEN, I. MOLENAAR and P. NIEUWENHUIS, J. Biomed. Mater. Res. 24 (1990) 529.

2. S. J. PETER, S. T. Miller, G. ZHU, A. W. YASKO and A. G. MIKOS, ibid. 41 (1998) 1.

3. M. J. BRUINING, H. G. T. BLAAUWGEERS, R. KUIJER, E. PELS, R. M. M. A. NUIJTS and L. H. K OOLE, Biomaterials 21 (2000) 595.

4. F. W. CORDEWENER, M. F. VAN GEFFEN, C. A. P. JOZIASSE, J. P. SCHMITZ, R. R. M. BOS, F. R. ROZEMA and A. J. PENNINGS, ibid. 21 (2000) 2433.

5. C. J. KIRKPATRICK and C. MITTERMAYER, J. Mater. Sci. Mater. Med. 1 (1990) 9.

6. A. Pizzoferrato, G. Ciapetti, S. SteA, E. CENNI, C. R. ARCIOLA, D. GRANCHI and L. S A V ARINO, Clin. Mater. 15 (1994) 173.

7. C. J. KIRKPATRICK, F. BITTINGER, M. WAGNER, H. KOHLER, T. G. VAN KOOTEN, C. L. KLEIN and M. OTTO, Proc. Inst. Mech. Eng. [H]. 212 (1998) 75.

8. A. DEKKER, C. PANFIL, M. VALDOR, G. PENNARTZ, H. RITCHER, C. MITTERMAYER and C. J. KIRKPATRICK, Cells Mater. 4 (1994) 101.

9. M. Allen, P. Millet, E. DAWES and N. RUSHTON, Clin. Mater. 16 (1994) 189.

10. C. R. CHU, A. Z. MONOSOV and D. AMIEL, Biomaterials. 16 (1995) 1381.

11. C. S. CHEN, M. MRKSICH, S. HUANG, G. M. WHITESIDES and D. E. INGBER, Science 276 (1997) 1425.

12. A. A. IGNATIUS and L. E. CLAES, Biomaterials 17 (1996) 831.

13. J. SugAnuma and H. Alexandre, J. Appl. Biomater. 4 (1993) 13.

14. E. J. BERGSMA, F. R. ROZEMA, R. R. BOS and W. C. DE BRUIJN, J. Oral Maxillofac. Surg. 51 (1993) 666.

15. B. SAAD, P. NEUENSCHWANDER, G. K. UHLSCHMID and U. W. SUTER, Int. J. Biol. Macromol. 25 (1999) 293.

16. T. YAMAOKA, Y. TAKAHASHI, T. FUJISATO, C. W. LEE, T. TSUJi, T. OHTA, A. MURAKAMI and Y. KIMURA, J. Biomed. Mater. Res. 54 (2001) 470.

17. D. J. AFRAMIAN, R. S. REDMAN, S. YAMANO, J. NIKOLOVSKI, E. CUKIERMAN, K. M. YAMADA, M. F. KRIETE, W. D. SWAIM, D. J. MOONEY and B. J. B A UM, Tissue Eng. 8 (2002) 649.

18. M. YANG, S. ZHU, Y. CHEN, Z. CHANG, G. CHEN, $\mathrm{Y}$. GONG, N. ZHAO and X. ZHANG, Biomaterials. 25 (2004) 1365.

19. O. BOSTMAN and H. PIHLA JAMAKI, ibid. 21 (2000) 2615.

20. R. L. REIS and A. M. CUNHA, J. Mater. Sci. Mater. Med. 6 (1995) 786.

21. M. G. CASCONE, N. BARBAni, C. CRistallini, P. GiUSti, G. CIARDELli and L. LAZZERI, J. Biomat. Sci. Polym. Ed. 12 (2001) 267.

22. W. S. HUNG, C. L. FANG, C. H. SU, W. F. LAI, Y. C. CHANG and Y. H. TS AI, J. Biomed. Mater. Res. 56 (2001) 93.

23. J. L. PARIENTE, B. S. KIM and A. ATAlA, ibid. 55 (2001) 33 .

24. A. OKAMURA, T. HIRAI, M. TANIHARA and T. Y AM A O KA, Polymer 43 (2002) 3549.

25. R. L. REIS, S. C. MENDES, A. M. CUNHA and M. J. BE V IS, Polym. Intern. 43 (1997) 347. 
26. P. B. MALAFAYA, C. ELVIRA, A. GALLARDO, J SAN ROMAN and R. L. REIS, J. Biomed. Sci. Polym. Edn. 12 (2001) 1227.

27. I. ESPIGARES, C. ELVIRA, J. F. MANO, B VÁZQUEZ, J. SAN ROMAN and R. L. REIS, Biomaterials 23 (2002) 1883.

28. M. E. GOMES, J. S. GODINHO, D. TCHALAMOV, A. M. CUNHA and R. L. REIS, Mat. Sci. Eng. C. 20 (2002) 19.

29. P. R. KINNEARD and C. D. GRAY, in "SPSS for Windows: Made Simple" (Psychology Press, Hove, 1999).

30. A. HENSTEN-PETTERSEN and K. HELGELAND, Scand. J. Dent. Res. 89 (1981) 102.

31. R. MACNAIR, E. H. RODGERS, C. MACDONALD, A. WYKMAN, I. GOLDIE and M. H. GRANT, J. Mater. Sci. Mater. Med. 8 (1997) 105.

32. W. GEURTSEN, F. LEHMANN, W. SPAHL and G. LEYHA USEN, J. Biomed. Mater. Res. 41 (1998) 474.

33. D. SGOURAS and R. DUNCAN, J. Mater. Sci. Mater. Med. 1 (1990) 61.

34. T. A. BEAN, W. C. ZHUANG, P. Y. TONG, J. D EICK, C. C. CHAPPELOW and D. M. YOURTEE, Dent. Mater. 11 (1995) 327.

35. J. W. CALVERT, K. G. MARRA, L. COOK, P. N KUMTA, P. A. DiMilla and L. E. WEISS, J. Biomed. Mater. Res. 52 (2000) 279.

36. A. VAN SLIEDREGT, J. A. VAN LOON, J. VAN DER BRINK, K. DE GROOT and C. A. VAN BLITTERSWIJK, Biomaterials 15 (1994) 251.

37. M. S. TAYLOR, A. U. DANIELS, K. P. ANDRIANO and J. HELle R, J. Appl. Biomater. 5 (1994) 151.

38. S. M. LI, H. GARREAU and M. VERT, J. Mater. Sci. Mater Med. 1 (1990) 131.
39. A. A. IGNATIUS, C. SCHMIDT, D. KASPAR and L. E. CLAES, J. Biomed. Mater. Res. 55 (2001) 285.

40. S. C. MENDES, R. L. REIS, Y. P. BOVELL, A. M CUNHA, C. A. VAN BLITTERSWIJK and J. D. DE B R U I J N, Biomaterials 22 (2001) 2057.

41. M. E. GOMES, R. L. REIS, A. M. CUNHA, C. A. BLITTERSWIJK and J. D. DE BRUIJN,ibid.22(2001) 1911.

42. A. P. MARQUES, R. L. REIS and J. A. HUNT, ibid. 23 (2002) 1471

43. H. LIAO, A. S. ANDERSSON, D. SUTHERLAND, S. PETRONIS, B. KASEMO andP. THOMSEN, ibid.24(2003) 649.

44. E. A. KAUFMANN, P. DUCHEYNE and I. M. SHAPIRO, J. Biomed. Mater. Res. 52 (2000) 783.

45. J. LINCKS, B. D. BOYAN, C. R. BLANCHARD, C. H. LOHMANN, Y. LIU, D. L. COCHRAN, D. D. DEAN and Z. SCHWARTZ, Biomaterials 19 (1998) 2219.

46. A. J. SALGADO, M. E. GOMES, A. CHOU, O. P. COUTINHO, R. L. REIS and D. W. HUTMACHER, Mat. Sci. Eng. C. 20 (2002) 27.

47. S. C. MENDES, J. BEZEMER, M. B. CLAASE, D. W GRIJPMA，G. BELLIA，F. DEGLI-INNOCENTI, R. L. REIS, K. DE GROOT, C. A. VAN BLITTERSWIJK and J. D. DE BRUIJN, Tissue Eng. 9 (Suppl 1) (2003) S91.

48. K. WEBB, V. HLADY and P. A. TRESCO, J. Biomed. Mater. Res. 49 (2000) 362.

49. I. PAShKuleVA, A. P. MARQUeS, F. VAZ and R. L. REIS, J. Mater. Sci. Mater. Med. (2004) 1.

Received 15 June

and accepted 17 December 2004 